Boyer, W., \& Crippen, C.L. (2014). Learning and teaching in the 21st century: An education plan for the new millennium developed in British Columbia, Canada. Childhood Education, 90(5), 343-353. DOI: http://doi.org/10.1080/00094056.2014.952218 [in English].

Cimatti, B. (2016). Definition, development, assessment of soft skills and their role for the quality of organizations and enterprises. International Journal for Quality Research, 10(1), 97-130. DOI: http://doi.org/10.18421/ijqr10.01-05 [in English].

The Future of Jobs Report. World Economic Forum, october 2020. URL: http://www3.weforum.org/docs/WEF_Future_of_Jobs_2020.pdf [in English].

УДК 378.046 .4

DOI: https://doi.org/10.35387/od.1(19).2021.102-113

Misailova Kseniia - PhD student at the Ivan Ziaziun Institute of Pedagogical and Adult Education of NAES of Ukraine; Head of the Aviation English Department at the Ivan Kozhedub Kharkiv National Air Force University

\begin{abstract}
Місайлова Ксенія Валентинівна - аспірантка Iнституту педагогічної освіти і освіти дорослих імені Івана Зязюна НАПН України; завідувачка кафредри авіаційної анелійської мови Харківського національного університету Повітряних Сил імені Івана Кожедуба
\end{abstract}

ORCID iD: https://orcid.org/0000-0001-5444-6823

E-mail:kseniiamisailova555@gmail.com

\title{
INTRODUCTORY TRAINING FOR AVIATION ENGLISH TEACHERS
}

Abstract. The article raises the issue of creating a system of introductory training for Aviation English teachers for successful realization of teaching in military and civilian institutions of higher education in the aviation industry.

A new scientific and pedagogical concept is introduced and argued, as «introductory training for teachers». Such training is necessary for teachers of higher educational establishments when transferring to higher positions into the institutions with another specialization, like transition from a civilian to a military institution to continue teaching career while teaching a foreign language for professional purposes. It was stressed in the article that in the context of transformation processes in Ukraine's transition to NATO and ICAO standards it is necessary firstly to train qualified teaching and instructional staff for the Air Force of the Armed Forces of Ukraine to ensure high quality of future specialists training.

The article considers the requirements set by the International Civil Aviation Organization (ICAO) for teachers who teach Aviation English to pilots and air traffic controllers in higher education institutions or on the basis of accredited training organizations. The conclusion on expediency and necessity 
to use these requirements to implement into the system of introductory training of Aviation English teachers in higher education establishments of Ukraine is made. There is also an approximate content of introductory training program for Aviation English teachers, as a result of which teachers will have an opportunity to acquire necessary knowledge and skills to teach Aviation English.

Key words: introductory teacher training; Aviation English teacher; teacher qualification; international requirements; ICAO; educational process; International Civil Aviation Organization; pilot; ATC; air traffic control; radio exchange.

\section{Місайлова Ксенія Валентинівна ПОПЕРЕДНЯ ПІДГОТОВКА ВИКЛАДАЧІВ АВІАЦІЙНОЇ АНГЛІЙСЬКОЇ МОВИ}

Анотація. У статmі актуалізовано питання створення системи попередньої підготовки викладачів англійської мови авіаційного профрілю для успішної реалізації педагогічної діяльності у військових $i$ цивільних закладах вищої освіти авіаційної галузі. Введено та обгрунтовано нове науково-педагогічне поняття - «попередня підготовка викладачів». Така підготовка необхідна викладачам вищої школи при переведенні на вищу посаду у заклад вищої освіти з іншою спеціалізацією, як перехід з цивільного закладу у військовий для проведення педагогічної діяльності, а саме викладання іноземної мови професійного спрямування. Наголошено на тому, що в умовах трансформаційних процесів при переході України на стандарти НАТО та IKAO, треба в першу чергу підготувати кваліфрікований педагогічний та інструкторський склад для Повітряних Сил Збройних Сил України, щоб в подальшому гарантувати високу якість підготовки майбутніх спеціалістів.

Автором проаналізовано вимоги, висунуті Міжнародною організацією иивільної авіації (IКАО) до викладачів, які викладають авіаційну англійську мову пілотам і диспетчерам з управління повітряним рухом у закладах вищої освіти або на базі акредитованих навчальних організацій. Зроблено висновок щодо доцільності та необхідності використання цих вимог для впровадження в систему профресійної підготовки викладачів авіаційної англійської мови в закладах вищої освіти України, а саме закладах вищої військової освіти авіаційного профілю.

Викладено орієнтовний зміст авторського курсу попередньої підготовки викладачів авіаційної англійської мови, в результаті проходження якого викладачі мають змогу набути необхідних знань $i$ навичок для викладання авіаційної англійської мови.

Ключові слова: попередня підготовка викладачів; викладач авіаційної англійської мови; кваліфрікація викладача; міжнародні вимоги; IКАО; освітній процес; міжнародна організація цивільної авіації; пілот; диспетчер; управління повітряним рухом; радіообмін. 
Problem statement and its rationale. In terms of European integration of Ukraine, the reform of the Armed Forces of Ukraine to achieve operational and technical interoperability with NATO countries, the introduction of advanced technologies to develop modern weapons, military equipment, information and logistical support of military operations and setting strategic communication in the defense sector, an effective system of aviation military specialists training up to modern standards the development of foreign language communication competence of aviation military specialists is of priority importance nowadays and after that bringing them to the high level of international language standards such as NATO standard STANAG 6001 and standards of the International Civil Aviation Organization (ICAO). Nowadays military aviation turns to a new international level. Participation in international exercises, peacekeeping operations, air show, flight control on international routes require a high level of foreign language communication, the ability to maintain radio communications in the air in English and have communication skills during non-standard and emergency situations in the air and of course operate aircraft technical terminology.

There is a close relationship and cooperation between civil and military aviation. Military aviation performs activities that are not purely military, such as aircraft move from one airfield to another, delivery of goods in the area of environmental protection and so on. For the positive experience of military pilots and air traffic controllers with civil aviation professionals they need to know and use military rules which made by civil aviation, namely, use norms and standards of ICAO including Aviation English standards.

So, the country is in great necessity of such kind of teachers of Aviation English and radiotelephony phraseology that can quickly and successfully adapt to language teaching to cadets of military aviation educational institutions, including the military system of training, professional training programs of students, lack of training hours in higher military education schools in Ukraine and the new global requirements for knowledge and proficiency of military aviation experts. So, we need to create in our country an effective system of Aviation English teachers training in order to meet all of these requirements.

Orientation and choice of the way of Ukraine towards NATO membership and at the same time the need to implement the ICAO standards and requirements require a substantial improvement in the content and methods of training teachers of English in aviation vocational education in Ukraine.

As mentioned above, in the context of transformation processes in Ukraine's transition to NATO and ICAO standards it is necessary to train qualified teaching and instructional staff for the Air Force of the Armed Forces of Ukraine firstly to ensure high quality of future specialists training. So, we propose to implement a new scientific and pedagogical concept as «introductory training for teachers» (ITT) that will help new teachers to integrate successfully into aviation military environment.

Such kind of training is necessary for teachers of higher educational 
establishments who plan to transfer to another educational institution with completely different specialization, like transition from a civilian to a military institution to continue teaching career while teaching a foreign language for professional purposes. A newly-hired teacher, having worked with civilian students, in civilian environment, having taught, for example, General English Course or Business English, will experience much difficulties starting teaching military cadets, in military environment, specialized Aviation English. He or she must be familiarized at first with psychological peculiarities of teaching militaries, principles of working in military environment, principles of working with adult learners, principles of future officers' work duties and responsibilities. That is why we assume that an introductory training for teachers will help greatly to achieve high results in teaching Aviation English to military personnel in Ukraine.

So, introductory training for Aviation English teachers must be based on philosophical, cultural, social, economic, psychological and pedagogical principles, to ensure social and governmental needs of the state and the individual needs of the individual, the conceptual ideas of continuity of learning; and on the basis of the system, andragogical, person-centered approaches. It has its own specific characteristics and features; is seen as an important component of economic development and conducted according to the requirements of the state.

The conceptual idea is based on an understanding of teacher professional development as a long-term process, which is carried out at the level of training in schools, and entry to the profession through continuing education within a career. Having researched the nature of Aviation English language teacher position, a teacher who works in this area requires sufficient long-term training to become familiar with the specific requirements that apply to military aviation professional language experts. There is a relatively small number of teachers who receive training that meets the special requirements for training pilots and air traffic controllers to manage air traffic.

Analysis of the recent publications. The problem of teaching staff development was examined by many scientists. The analysis of scientific works testifies to the interest of researchers in determining the content of the concept and components of the teachers' competencies (Yelnikova, 2014), Oliynyk, 2003), Kalinin, 2004), Fursenko, 2016) and others). Thus, the requirements for the professional competence of research and teaching staff of the universities in terms of creating an electronic educational environment considered in the paper by Kocharyan A. (2014). Kalinin V. (2004) considered features of formation of professional competence of the future foreign language teacher in new language policy; Yelnikova G. (2014) described professional improvement of teachers at vocational institutions, and Oliynyk V. (2003) on the basis of the problems analysis of pedagogical staff professional improvement suggested ways to solve them. Fursenko T. (2016) outlined the requirements for the professional competence of a teacher of linguistic disciplines in a non-language institution of higher education.

However, only Petraschuk O. (2017) began to talk about the 
competences of Aviation English teachers and their qualifications, and depicted the requirements of International Civil Aviation Organization to the Aviation English teacher qualification. The problem is raised but there is no solution how to train such a highly qualified teacher that can meet all those requirements.

So, the purpose of the article is to show the necessity of specialized introductory training for Aviation English teachers and to present oriented content of such a program.

Presentation of the basic material. According to the Compendium «Designing Effective Pre-Service Teacher Education Programs» created by Irfan Muzaffar, Hiba Rahim, and Cassandra Jessee introductory teacher training (ITT) programs are the first form of professional study that individuals complete to enter the teaching profession as a newly-hired teacher. These programs typically consist of a blend of theoretical knowledge about teaching and a fieldbased practice experience. The quality of training provided through ITT programs affects teachers' practice, effectiveness, and career commitment (Irfan Muzaffar, 2011).

The quality of teaching and learning taking place in the classroom therefore depends on and reflects the quality of ITT programs. Because student achievement depends significantly on the quality of teachers, which in turn depends on the quality of ITT programs, developing and preserving high-quality of ITT programs can go a long way in the success of development activities that aim to improve the quality of teaching and learning for all students (Fursenko, 2016). From a larger perspective, ITT programs are part of what scholars of teaching call a continuum of learning how to teach, as illustrated in Figure 1. As part of this continuum, the introductory programs are also regarded as foundational building blocks for career-long professional development. In most developing contexts, the ITT programs are regulated by the governments and implemented by institutions accredited by the ministries of education for licensing and certification of teachers.

So, there are four steps in the process of «learning how to teach». The first one is the apprenticeship of observation, the period when a newly hired teacher observes professionals. The second step is the period when a teacher should complete a training or preparation course in order to acquire the necessary knowledge and skills to be an effective Aviation English teacher. The third step is induction that is related to the first year of teaching in a new higher education institution. And it is obvious, that this process is a lifelong one that will go on during the whole period of teaching through continuous professional development (CPD). CPD is the process when a teacher takes part in in-service training to refresh and upgrade his or her knowledge, skills, and qualifications. 


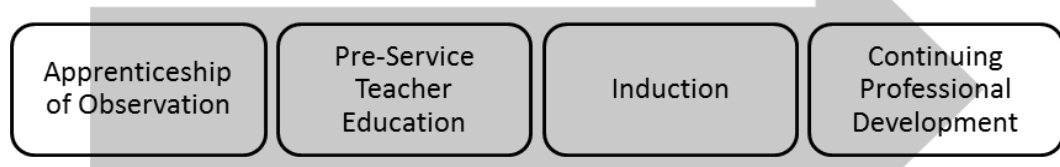

Figure 1. Continuum of Learning How to Teach

The usual academic qualification required for native English-speaking teachers of English across North America, Western Europe, Australia and New Zealand is typically a master's degree in Teaching English as a Second Language (TESL) or some other closely related field, such as Applied Linguistics. In other parts of the world, Ukraine, Eastern Europe, Asia, the academic qualification to become a language teacher is usually a bachelor's degree in foreign language training. Other «language-related» academic fields (such as Literature, Comparative Literature, Communications, Translation/Interpretation studies, Comparative Linguistics or "pure» Linguistics) do not focus on language training or language learning and are not relevant qualifications for language teachers.

Good knowledge in the field of radio communication is very important to teach aviation language. There is a number of tools to help teachers to acquire this particular language skill. They can take lessons how to control the aircraft; undergo training from an experienced teacher of aviation language; gain real experience of learning the language of aviation; communicate with professional pilots and ATC; reading professional literature and other forms of learning. If the teacher is not familiar with aviation language, it is important to be able to work «in tandem» with expert subject (Petrashchuk, 2017).

Additional qualifications may include the presence of cross-cultural competence, international experience, the experience of learning a second language and multilingualism, of course, a strong desire to engage in teaching work.

Proficiency of teachers of aviation English language listed in document ICAO Doc 9835 (Organization, 2010), is divided into "excellent», "very good» and «minimum». These categories account for education, familiarity with communication and experience in aviation training.

Although the educational level, experience and knowledge of teachers must meet certain basic requirements, when evaluating teachers, it is necessary to consider their overall profile, including components such as attitude to work, sensitivity, curiosity, creativity, attention to intercultural issues and the ability to use and share their experience (Organization, ICAO Doc 323 Guidelines of Aviation English Training Programs, 2009).

Here are some qualities - both formal and informal - that the Aviation English teacher should possess: 
- $\quad$ experience in teaching subject courses in English;

- familiarity with aviation communications and operational situations and conditions;

- deep knowledge of ICAO Document 9835 Manual on the Implementation of ICAO Language Proficiency Requirements; ICAO Cir 323 Guidelines for Aviation English Training Programmes, ICAO Cir 318 Language Testing Criteria for Global Harmonization;

- experience of teaching communication techniques;

- intercultural awareness;

- curiosity;

- commitment to continuous professional development;

- $\quad$ the ability to improve and control the process of learning;

- $\quad$ ability to motivate students and to assist them;

of safety;

- familiarity with aspects of language that may be decisive in terms

- ability to assess proficiency in terms of situational effectiveness, rather than linguistic correctness;

- desire to support, to coordinate, promote and improve the interaction between the audience and not just "teaching" (ie, knowledge transfer);

- awareness of the differences between the standard spoken language and phraseology in radio exchange.

There are, however, personality traits characteristic of teaching Aviation English in the context of the requirements to ICAO language proficiency, and these features should always occur in the teacher.

So, when teachers are new in the organization (even if they have had experience before), new-teacher transitional training can be particularly vital to their success because it facilitates their adaptation to the predominant learning and teaching philosophies of the institution that they are joining (MaryAnn Christison, 2015).

Taking into consideration the information mentioned above, it is possible to create an introductory training program for newly hired Aviation English teachers, based on principals of systemacity, consistency and intensity. This course was piloted in 2020-2021 Academic year in Ivan Kozhedub Kharkiv National Air Force University, particularly on the Aviation English department (table 1).

Table 1

Proposed introductory training program content for Ivan Kozhedub Kharkiv National Air Force University teachers (2020-2021 Academic year)

\begin{tabular}{|c|c|c|c|}
\hline No. & Stage & Topics & Duration \\
\hline I. & 릉 등 & $\begin{array}{l}\text { Air Forces of Ukraine mission, vision, structure, } \\
\text { international military cooperation. } \\
\text { The urgent necessity of English for aviation military } \\
\text { personnel, international certificates of level of }\end{array}$ & 2 hours \\
\hline
\end{tabular}




\begin{tabular}{|c|c|c|c|}
\hline & & English. & \\
\hline II. & & $\begin{array}{l}\text { Ivan Kozhedub Kharkiv National Air Force } \\
\text { University (KhNAFU) mission, vision, history, } \\
\text { organizational chart, regulatory documents, } \\
\text { statutes. } \\
\begin{array}{l}\text { Aviation English Department mission, vision, } \\
\text { history, organizational chart, regulatory } \\
\text { documents, statutes. }\end{array}\end{array}$ & 2 hours \\
\hline III. & & $\begin{array}{l}\text { Aviation English teacher for the military personnel } \\
\text { - duties, guidelines, essential documents, } \\
\text { curriculum, formats of lesson plans, teaching aids, } \\
\text { teaching materials, standards, skills development, } \\
\text { international cooperation, values, code of ethics of } \\
\text { the department, dress code. }\end{array}$ & 3 hours \\
\hline IV. & & $\begin{array}{l}\text { Administrative responsibilities and duties, Labor } \\
\text { legislation, rewards and punishment }\end{array}$ & 1 hour \\
\hline \multirow[t]{4}{*}{ V. } & \multirow[b]{4}{*}{ 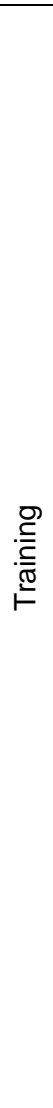 } & General Technical knowledge course (in Ukr.) & 30 hours \\
\hline & & Military Psychology course (in Ukr.) & 6 hours \\
\hline & & $\begin{array}{l}\text { Andragogy and Teaching Adults peculiarities } \\
\text { (in Ukr.) }\end{array}$ & 6 hours \\
\hline & & $\begin{array}{l}\text { Military Environment Awareness course (in } \\
\text { Eng.): } \\
\text { - Services and braches } \\
\text { - Military units, - Military ranks, - Military career, - } \\
\text { Military uniform, - Military training } \\
\text { - Basic political-military issues (NATO, PfP, UN } \\
\text { troops, peacekeeping, joint training exercises, } \\
\text { military reforms) } \\
\text { - NATO (political goals and basic tasks, strategic } \\
\text { concept, NATO enlargement) } \\
\text { - Peacekeeping (the world's hot spots, } \\
\text { participation in peacekeeping / peace support } \\
\text { operations, international cooperation) } \\
\text { - Military reform (reorganization, reduction and } \\
\text { modernization of the military force, professional } \\
\text { military, military cooperation) } \\
\text { - Present armed conflicts (wars, conflicts in Europe } \\
\text { and other parts of the world, causes of conflicts, } \\
\text { conflict prevention) } \\
\text { - International relations (PfP, NATO, international } \\
\text { institutions, joint operations, military exercises) } \\
\text { - Defense policy (strategic concepts, national } \\
\text { military strategy, military doctrines) } \\
\text { - Defense planning (defense spending, military } \\
\text { budget, force planning, force goals) } \\
\text { - Non-military security challenges (terrorism, other } \\
\text { non-traditional threats) }\end{array}$ & 30 hours \\
\hline
\end{tabular}




\begin{tabular}{|c|c|c|c|}
\hline & & $\begin{array}{l}\text { - Armed conflicts (hot spots, low-intensity conflicts, } \\
\text { conflict prevention) } \\
\text { - Peace support (peacekeeping, peace } \\
\text { enforcement, post-conflict reconstruction) } \\
\text { - Security issues (balance of power, nuclear } \\
\text { deterrence, arms control, collective security, } \\
\text { regional security issues) } \\
-\quad \text { Infrastructure (weapon systems, military } \\
\text { equipment, military research and development) } \\
\text { - Military transformation (force restructuring, } \\
\text { modernization issues) } \\
\text { - International military law (Geneva Conventions, } \\
\text { war crimes, legality of the use of force) } \\
- \text { Environmental security (wartime impacts, } \\
\text { weapons testing and disposal, other } \\
\text { environmental concerns) } \\
-\quad \text { Military and society (terms and conditions of } \\
\text { service, civil-military relations) }\end{array}$ & \\
\hline & & $\begin{array}{l}\text { Visiting aerodromes, aviation military bases, flight } \\
\text { simulators. } \\
\text { Performing a flight with instructor on different types } \\
\text { of aircraft. }\end{array}$ & 30 hours \\
\hline & & $\begin{array}{l}\text { Aviation Awareness and Aviation English } \\
\text { course (in Eng.): } \\
\text { - Air Law, Aviation Security, Flight Safety, } \\
\text { International Organizations, Air Operations } \\
\text { - Human Factors, Crew Resource Management } \\
\text { (CRM) } \\
\text { - In-flight incidents and emergency situations } \\
\text { - Navigation and charts, Meteorology and } \\
\text { environmental hazards } \\
\text { - Airport environment and ground operations } \\
\text { - Aircraft systems and flight, Airspace and types of } \\
\text { ATC } \\
\text { - Flight operations, airlines and staff } \\
\text { - Standard radiotelephony phraseology }\end{array}$ & 60 hours \\
\hline & & Aviation English Terminology course (in Eng.). & 60 hours \\
\hline & & Aviation English Methodology (in Eng.). & 4 hours \\
\hline & & $\begin{array}{l}\text { ICAO and STANAG standards, levels } \\
\text { requirements, testing procedures and evaluation } \\
\text { scales (in Eng.). }\end{array}$ & 2 hours \\
\hline & & $\begin{array}{l}\text { Familiarization with electronic educational aids, } \\
\text { used in the department (computers, projectors, } \\
\text { printers, language laboratory, computer simulators } \\
\text { and teaching software). (in Ukr.) }\end{array}$ & 6 hours \\
\hline VI. & 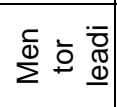 & $\begin{array}{l}\text { Lesson observations. } \\
\text { Analyzing lesson videos. } \\
\text { Final demonstration lesson. }\end{array}$ & 30 hours \\
\hline
\end{tabular}




\begin{tabular}{|l|l|l|l|}
\hline & $\begin{array}{l}\text { Receiving the ICAO approved certificate after } \\
\text { taking the Aviation English course for instructors } \\
\text { and raters organized by ICAO Institute, Kyiv. } \\
\text { Taking part in conferences, seminars, workshops } \\
\text { (organized by BILC - The Language Standards } \\
\text { and Assessment Seminar (LSAS), The English } \\
\text { Teaching Faculty Development Workshop). }\end{array}$ & During the \\
& year \\
\hline \\
TOTAL DURATION OF THE COURSE & 272 hours \\
\hline
\end{tabular}

Conclusions and prospects for further research. As one can see from the research, considering the globalization processes in the world and European integration processes in Ukraine there is a great necessity to improve the level of English of the military personnel and aviation specialists, in particular. But at the very beginning teachers must be trained properly in order to perform this task. So, it is necessary to implement so called «introductory training for teachers» who start their work in higher military educational establishments in the field of aviation in Ukraine. The program that was created covers all the essential topics and fields of studies to prepare the newly-hired teacher to teach military aviators. It consists of 3 parts: Introduction and Familiarization, Training and Mentor Leading and Assessment. It will last for approximately 2 months and will help him or her to adapt to new work conditions. After having trained according to this program, a new teacher will definitely show excellent results of his job in a shorter period of time and the cadets won't decrease their level of Aviation English.

\section{Список використаних джерел}

Єльникова, Г.В. (2014). Підвищення кваліфікації педагогічних працівників у т. ч. керівників, професійно-технічних навчальних закладів, навчання на підприємстві. Теорія і методика профресійної освіти, $1,5,1-13$.

Калінін, В.О. (2004). Особливості формування професійної компетентності майбутнього вчителя іноземної мови в новій мовній політиці. Формування профресійної компетентності майбутнього вчителя іноземної мови засобами інноваційних освітніх технологій: зб. наук. праць. Житомир: ЖДУ ім. І. Франка, 193-196.

Кочарян, А.Б. (2014). Вимоги до професійної компетентності науковопедагогічних працівників університету за умов створення електронного освітнього середовища. Комп'ютер у школі та сім'ї, 4, 16-18.

Олійник, В.В. (2003). Наукові основи управління підвищенням кваліфрікації педагогічних працівників профотехосвіти. Монографія. Київ, Міленіум, 594 c.

Фурсенко, Т.М. (2016). Вимоги до професійної компетентності викладача лінгвістичних дисциплін у немовному ВНЗ. Актуальні проблеми формування англомовної компетенції для спеціальних цілей: компетентнісна парадигма: Міжвуз. наук.-практ. конфр. Київ: НАУ. 
Irfan Muzaffar, H.R. (2011). Designing Effective Introductory Teacher Education Programs. USA: American Institutes for Research.

MaryAnn Christison, F.L. (2015). A Handbook for Language Program Administrators. USA: ALTA English Publishers.

Organization, I.C. (2009). Doc ICAO 323 Guidelines for Aviation English Training Programs. Montréal, Quebec, Canada: International Civil Aviation Organization.

Organization, I.C. (2010). Doc 9835 Manual on the Implementation of ICAO Language Proficiency Requirements. Montréal, Quebec, Canada: International Civil Aviation Organization.

Petrashchuk, O. (2017). Defining Competency and Excellence in Teaching Aviation English. The International Journal for ESP Practitioners, 03, 7-13.

Petrashchuk, O. (2016). Defining Competency Qualification of Aviation English Instructor. Warsow: Studi@ Naukowe: Changing Perspectives on Aviation English Training, 29 (2), 73-79.

\section{References (translated and transliterated)}

Yelnykova, G. (2014). Pidvyshchennia kvalifikatsii pedagogichnyh pratsivnykiv u t.ch. kerivnykiv, profesijno-tehnichnyh navchalnyh zakladiv, navchannia na pidpryemstvi [Pedagogical staff qualification improvement, including managers, at vocational educational establishments, studying at enterprises]. In Teoriia i metodyka profesijnoi osvity - Theory and Methodic of Professional Education, 1, 5, 1-13 [in Ukrainian].

Kalinin, V. (2004). Osoblyvosti formuvannia profesijnoi kompetentnosti majbutniogo vchytelia inozemnoi movy v novij movnij politytsi [Future Foreign Language Teacher Professional Competence Formation Peculiarities in terms of new liguistic policy]. In: Formuvannia profesijnoi kompetentnosti majbutniogo vchytelia inozemnoi movy zasobamy innovatsijnyh tehnologij - Formation of the professional competence of a future Foreign Language Teacher by means of innovation educational technologies. Zhytomyr: Franko ZhDU, 193-196 [in Ukrainian].

Kotcharian, A. (2014). Vymohy do profesijnoi kompetentnosti naukovopedagogichnyh pratsivnykiv universytetu za umov stvorennia elektronnogo osvitniogo seredovyshcha [Requirements to professional competence of the Academic staff of the University under conditions of electronic educational environment creation]. Kompjuter u shkoli i simji - Computer at school and in the family, № 4, 16-18 [in Ukrainian].

Olijnyk, V. (2003). Naukovi osnovy upravlinnia pidvyshchenniam kvalifikatsii pedagogichnyh pratsivnykiv proftehosvity [Scientific fundamentals of vocational education pedagogical staff professional improvement]. Monograph.: Kyiv, Milenium, 594 p. [in Ukrainian].

Fursenko, T.M. (2016). Vymohy do profesiinoi kompetentnosti vykladacha linhvistychnykh dystsyplin u nemovnomu VNZ [Requirements for the professional competence of a teacher of linguistic disciplines in a nonlanguage university]. In: Aktualni problemy formuvannia anhlomovnoi kompetentsii dlia spetsialnykh tsilei: kompetentnisna paradyhma - Actual problems of formation of English-language competence for special 
purposes: competence paradigm: Mizhvuz. nauk.-prakt. konf. Kyiv: NAU [in Ukrainian].

Irfan Muzaffar, H.R. (2011). Designing Effective Introductory Teacher Education

Programs. USA: American Institutes for Research [In English].

MaryAnn Christison, F.L. (2015). A Handbook for Language Program Administrators.

USA: ALTA English Publishers [In English].

Organization, I.C. (2009). Doc ICAO 323 Guidelines for Aviation English Training Programs. Montréal, Quebec, Canada: International Civil Aviation Organization [In English].

Organization, I.C. (2010). Doc 9835 Manual on the Implementation of ICAO Language Proficiency Requirements. Montréal, Quebec, Canada: International Civil Aviation Organization [In English].

Petrashchuk, O. (2017). Defining Competency and Excellence in Teaching Aviation English. The International Journal for ESP Practitioners, 03, 7-13 [In English].

Petrashchuk, O. (2016). Defining Competency Qualification of Aviation English Instructor.Warsow, Studi@ Naukowe: Changing Perspectives on Aviation English Training, 29: (2), 73-79 [In English].

УДК 378,004.9:378

DOI: https://doi.org/10.35387/od.1(19).2021.113-122

Султанова Лейла Юріївна доктор педагогічних наук, старший науковий співробітник, завідувач відділу теорії $i$ практики педагогічної освіти Iнституту педагогічної освіти $i$ освіти дорослих імені Івана Зязюна НАПН України
Sultanova Leila - Doctor of Pedagogical Sciences, Senior Researcher, Head of the Department of Theory and Practice of Pedagogical Education of the Ivan Ziaziun Institute of Pedagogical Education and Adult Education of the NAES of Ukraine

ORCID iD: http://orcid.org/0000-0002-3324-6926

E-mail: leilasultanova22.07@gmail.com

\section{МОДЕЛЬ ФОРМУВАННЯ СУБ'ЄКТИВНОГО ОБРАЗУ ПРОФЕСІЙНОГО МАЙБУТНЬОГО СТУДЕНТІВ ГУМАНІТАРНОГО ПРОФІЛЮ У ЗАКЛАДАХ ВИЩОЇ ОСВІТИ}

Анотація. У статті обгрунтовано модель фрормування суб'єктивного образу професійного майбутнього студентів гуманітарного профрілю. Представлено узагальнене визначення моделювання як методу науковго пізнання й визначено специфрічні особливості моделювання. Охарактеризовано етапи моделювання (постановка завдання; створення (вибір) моделі; дослідження моделі; перенесення знань про модель у знання про оригінал; перевірка істинності отриманих за допомогою моделі даних). Обгурнтовано логіку вибору структурно-фрункціональної моделі для дослідження процесу 